PROTEOME SCIENCE

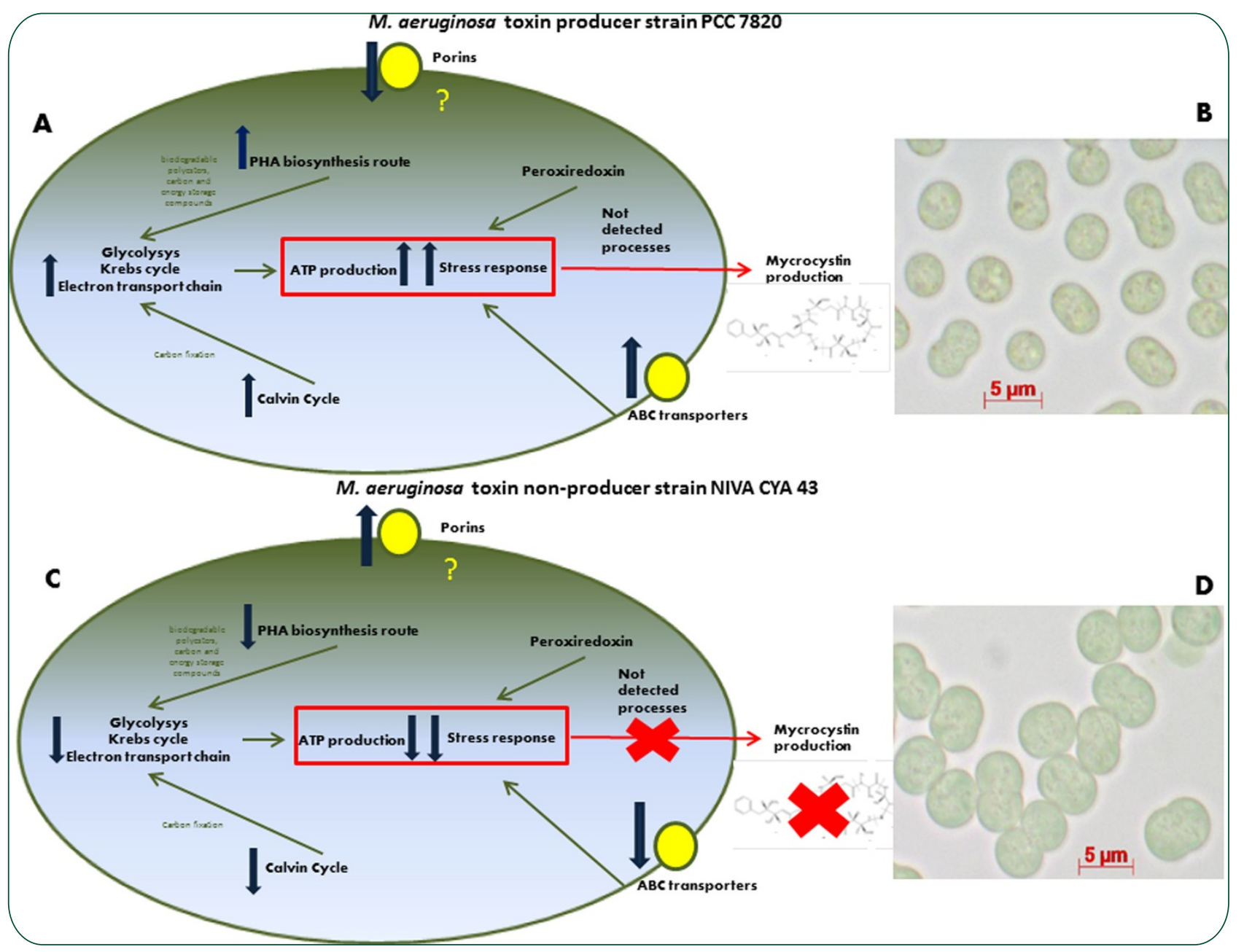

\title{
Comparative proteomics between natural Microcystis isolates with a focus on microcystin synthesis
}

Tonietto et al. 


\title{
Comparative proteomics between natural Microcystis isolates with a focus on microcystin synthesis
}

\author{
Ângela Tonietto ${ }^{1}$, Bernardo A Petriz , Wérika C Araújo ${ }^{1}$, Ângela Mehta², Beatriz S Magalhães ${ }^{1}$ \\ and Octávio L Franco ${ }^{1,3^{*}}$
}

\begin{abstract}
Background: Microcystis aeruginosa is a species of cyanobacteria commonly found in a number of countries and frequently related to animal poisoning episodes due to its capacity to produce the cyanotoxin known as microcystin. Despite vast literature on microcystin structures and their deleterious effects, little is known about its synthesis by cyanobacteria. Therefore, this study used proteomic tools to compare two M. aeruginosa strains, contrasting them for microcystin production.

Results: 2-DE gels were performed and 30 differential protein spots were chosen. Among them, 11 protein spots were unique in the toxin producing strain and 8 in the non-toxin producing strain, and 14 protein spots were shown on both 2-DE gels but expressed differently in intensity. Around $57 \%$ of the tandem mass spectrometry identified proteins were related to energy metabolism, with these proteins being up-regulated in the toxin producing strain.

Conclusions: These data suggest that the presence of higher quantities of metabolic enzymes could be related to microcystin metabolism in comparison to the non-toxin producing strain. Moreover, it was suggested that the production of microcystin could also be related to other proteins than those directly involved in its production, such as the enzymes involved in the Calvin cycle and glycolysis.
\end{abstract}

Keywords: Cyanobacteria, Microcystis aeruginosa, Cyanotoxin, Proteome

\section{Background}

Microcystis aeruginosa, a worldwide species of cyanobacteria, is frequently related to toxic water blooms. These blooms have occurred in many countries, such as the Philippines [1], Australia [2], the United States of America [3], Canada [4] and Brazil [5], causing water contamination, risk of toxicity for hemodialysis and fishing prohibition. Moreover, numerous cases of animal poisoning due to cyanotoxins have been documented worldwide (livestock stupor in Australia [6], fish deaths in the U.K. [7] and cattle deaths in Switzerland [8]).

\footnotetext{
* Correspondence: ocfranco@gmail.com

'Centro de Análises Proteômicas e Bioquímicas, Universidade Católica de Brasília, Pós Graduação em Ciências Genômicas e Biotecnologia, SGAN 916 Norte Av. W5, Brasilia, DF, Brazil

${ }^{3}$ Departamento de Biologia, Universidade Federal de Juiz de Fora, Juiz de Fora, MG, Brazil

Full list of author information is available at the end of the article
}

Nevertheless, the most serious case of human poisoning attributed to cyanotoxins in drinking water, called "Caruaru syndrome", occurred in Brazil, in 1996, when 76 patients died after hemodialysis treatment $[9,10]$. The deaths were attributed to the cyanotoxins microcystin and cylindrospermopsin.

$M$. aeruginosa is able to produce the hepatotoxin microcystins [11], which are members of a remarkable family of more than 90 cyclic peptides that inhibit hepatic serine/threonine protein phosphatases PP1 and PP2A of terrestrial mammals [12]. Furthermore, it is well-known that environmental factors - such as temperature, light intensity, nutrients, salinity, $\mathrm{pH}-$ and culture age can induce changes in toxicity and toxin concentration [13-15]. Despite the $M$. aeruginosa genome having already been completely sequenced, the cyanobacteria metabolic pathway of microcystin

\section{Biomed Central}


production has not been completely elucidated [16]. Otherwise, the microcystin biosynthetic gene cluster has already been characterized in Microcystis [17], Planktothrix [18], and Anabaena [19]. In this field, a proteomic approach could help to shed some light on toxin production. Nevertheless, only a few studies of cyanobacteria have been conducted using proteomic tools, being basically restricted to the Synechocystis species [20-24]. Furthermore, most of these studies focus on a specific compartment, such as the thylakoid membrane [23], outer membrane [21], plasma membrane [22], periplasm and cytoplasm [25,26]. Other cyanobacteria species, however, have also been proteomically considered, such as Anabaena variabilis [27], Anabaena sp. PCC 7120 [28,29], Nostoc punctiforme [30,31], Nevertheless these studies have been restricted to structural proteomic descriptions.

Otherwise, comparative proteomics have also been used to find differentially expressed proteins of cyanobacteria in response to environmental stresses like salinity [32,33], light [34,35], temperature [36], and $\mathrm{pH}[37]$. Some studies have highlighted cyanobacterial changes becoming adapted to the symbiosis state $[38,39]$. However, the majority of studies have been done with Synechocystis sp. PCC 6803. Environmental conditions, like higher or lower salinity, acidity, variation of $\mathrm{CO}_{2}$ and $\mathrm{Fe}^{2+}$ concentration are directly related to cyanobacteria development in the natural environment. Therefore, it is important to perceive how cyanobacteria respond to these environmental changes to better understand the bloom formation processes.

Considering the enormous worldwide importance of M. aeruginosa in relation to freshwater quality, especially for public supply in reservoirs, it is interesting to note the low-quantity of research in proteomics [40,41] with comparative proteomics related to microcystin biosynthesis. To this end, this work aims to compare one naturally toxin-producing strain of $M$. aeruginosa with another naturally non-toxin producing strain using proteomic tools in order to better understand toxin production.

\section{Results and discussion}

\section{Growth curves and microcystin detection}

Aiming to compare two $M$. aeruginosa strains according their ability to produce cyanotoxins, both were growth in liquid medium according description previously described in literature. Although the differences are slight, there is correspondence between curves shown regardless of the wavelength used (Additional file 1: Figure S1). Microcystins are continuously produced during the cyanobacterial life cycle, but large quantities are commonly found at the end of log phase. For this reason, protein collection occurs at this growth point (Additional file 1: Figure S1, arrows) in which intracellular microcystin concentration is typically higher as previously observed for M. aeruginosa PCC 7820 [42].

In order to confirm if the M. aeruginosa strain PCC 7820 is really toxin producing and also if NIVA CYA 43 is really a non-toxin producing strain, the presence of microcystins in both cultures were analyzed in C18 column reversed-phase HPLC [Figure 1a]. The fraction indicated by the arrow was eluted only from the $M$. aeruginosa PCC 7820 extract after 7 min $48 \mathrm{~s}$, with $40.7 \%$ acetonitrile. This fraction was concentrated, resuspended in a saturated solution of $\alpha$-cyano-4-hydroxycinnamic acid matrix and analyzed by MALDI-TOF/TOF. The MS spectra showed that the fraction contained at least three different variants of microcystins [Figure 1b]. Microcystin-LR $(\mathrm{m} / z$ 995) was the variant with the most intensive ions. The other detected ions were identified as [Dha] microcystin-LR $(\mathrm{m} / \mathrm{z}$ 981), [D-Asp ${ }^{3}$, Dha $\left.^{7}\right]$ microcystin-RR, microcystin-LW and [D-Asp ${ }^{3}$, ADMAdda $^{5}$ ]microcystin-LR, according to MS data comparison in the literature [43-45].

The observation of more than one microcystin variant was not surprising, because several cyanobacteria may be able to produce more than one microcystin variant [14]. Besides, in 50 to $75 \%$ of cyanobacterial blooms, toxicity is associated with the simultaneous production of several cyanotoxins [46].

\section{Proteome of $M$. aeruginosa}

SDS-PAGE (Additional file 2: Figure S2) was used to evaluate the protein extraction protocol quality, the reproducibility of the protein preparations, and to quantify the protein extracts for preparative 2-D gel analyses. For 2-DE, each strain was cultured in triplicate. From each biological replication, proteins were extracted from the whole-cell lysate. The M. aeruginosa PCC 7820 sample showed well-resolved protein bands with molecular masses between 10 and $116 \mathrm{kDa}$. Similar data was obtained from the $M$. aeruginosa NIVA CYA 43 sample (Additional file 2: Figure S2). In order to better investigate differential protein abundance visualized by SDSPAGE, 2-DE analyses were performed. Protein extraction followed the same protocol used for SDS-PAGE, with the addition of a cleaning-up step, as described in the methodology. About 220 protein spots became visible and were clearly resolved in $M$. aeruginosa PCC 7820 2-DE [Figure 2a] and about 202 protein spots in $M$. aeruginosa NIVA CYA 432 -DE [Figure 2b]. The majority of spots were observed between $\mathrm{pH} 4$ and 7 , as previously described for Anabaena variabilis [27], Synechococcus sp. PCC 7942 [47], and for Synechocystis sp. PCC 6803 [23]. This was the protein pattern expected for cyanobacteria samples, although most cyanobacterial proteomic studies have used strips with narrower pI ranges (4-7) and/or subproteomes from fractionation methods $[20,22,23,35,37,39,40,48]$. These 


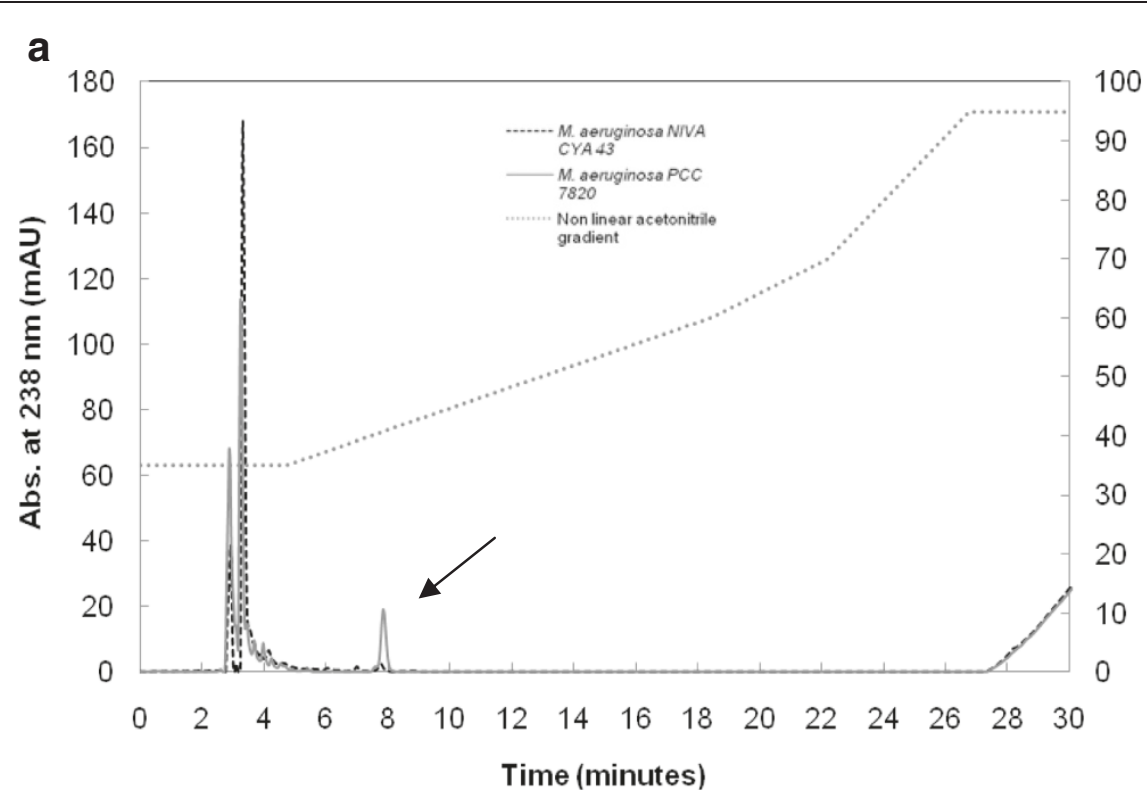

b

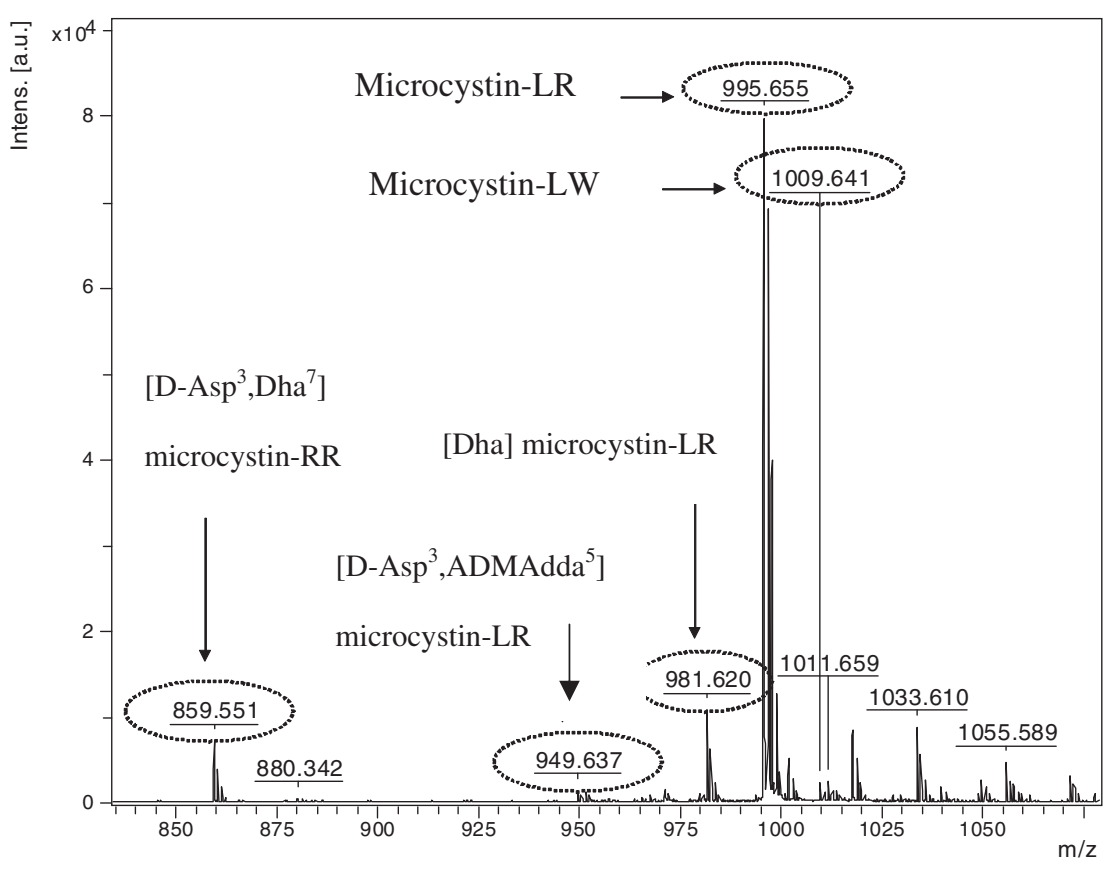

Figure 1 (a) M. aeruginosa sample analysis in HPLC - reverse phase C18 column - and detection in $238 \mathrm{~nm}$, following a non-linear gradient from $35 \%$ to $95 \%$ of acetonitrile/TFA $0.1 \%$. The fraction indicated by an arrow was evaluated by MALDI-TOF/TOF. (b) Mass spectra obtained by MALDI-TOF/TOF from M. aeruginosa PCC 7820 extract eluted fraction in HPLC and respective microcystin variant identifications.

studies have provided valuable information, but for Microcystis, we thought it more appropriate to expand the $\mathrm{pI}$ range and protein solubility (by adding Triton-X-100) to provide a more global profile, considering that this is the first report that compares one naturally toxin-producing strain with another naturally non-toxin-producing strain of M. aeruginosa.

\section{Identification and functional classification of the differentially expressed proteins}

BioNumerics, software version 4.6 , was used to analyze gel images in order to detect and select spots of interest. The five gel images obtained for each strain (biological replicates) were compared. At the end of the analysis, the software had provided volume values for each spot 


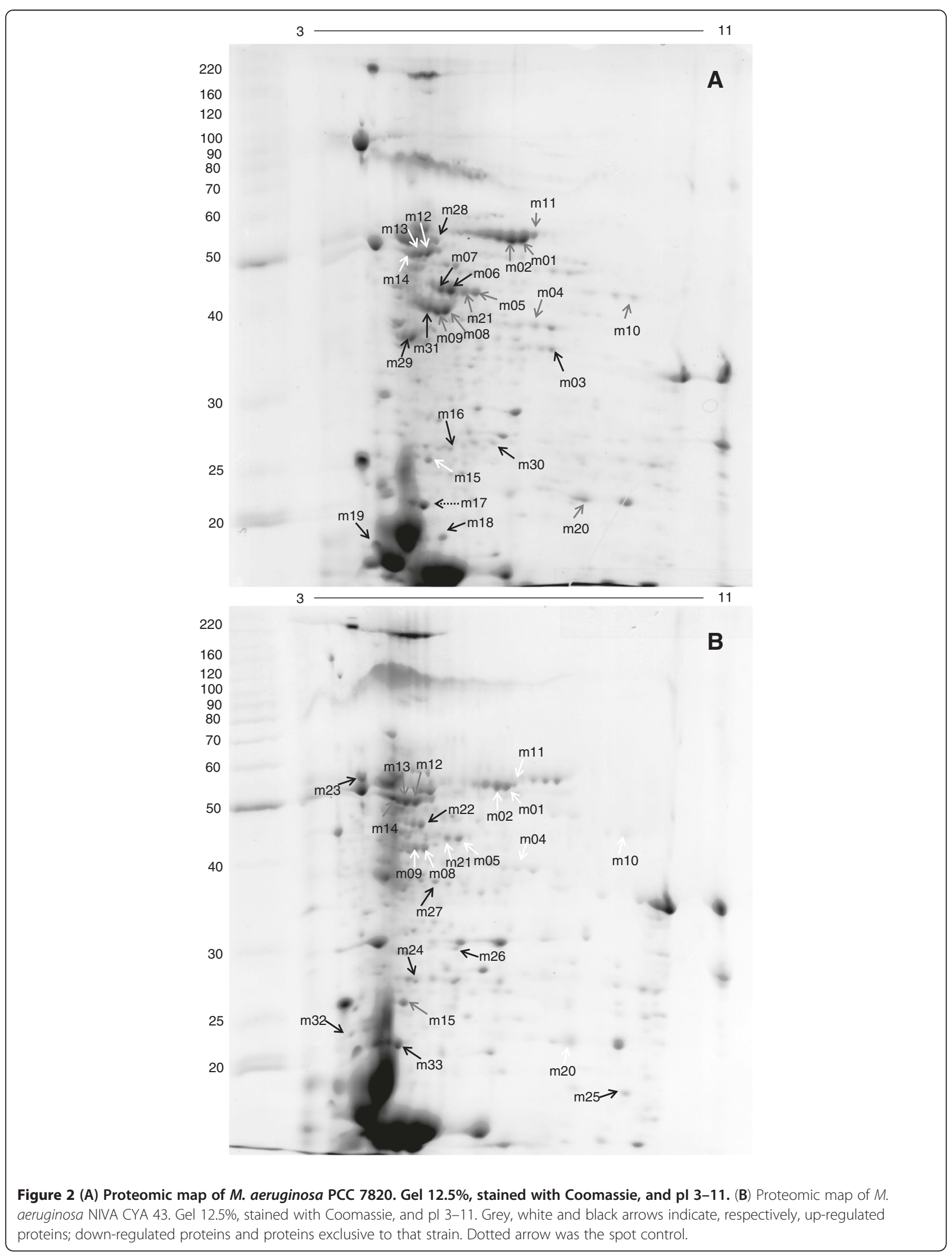


detected. With this information, linear regression analyses were done, and thus $\mathrm{r}^{2}$ was calculated. The linear regression presented $r^{2}=0.75$ for $M$. aeruginosa PCC 7820 quintuplicates and $\mathrm{r}^{2}=0.70$ for $M$. aeruginosa NIVA CYA 43. Linear regression analyses of technical replicate gels commonly showed correlations higher than $0.80[49,50]$. It is important to highlight that in this study, we worked with biological replicates, and therefore the $\mathrm{r}^{2}$ value was slightly lower. Theoretical $\mathrm{Mr}$ and $\mathrm{pI}$ were obtained from MASCOT analysis and compared with the experimental values that were estimated directly from the gel images, using BioNumerics software. Moreover, toxinproducing cyanobacterial protein spots were considered differentially expressed when present/absent in all replicates: when at least two-fold changed (up or down) compared to control (non-toxin-producing) and also when the standard deviation bars did not intercross. There was a well-defined correlation between the theoretical and experimental Mr values as shown in Table 1.

After the BioNumerics software analyses, 30 proteins of interest were chosen for identification based on differential expression. These proteins were identified by MASCOT and corresponded to 21 different proteins classes [Table 1]. Almost all identified proteins showed sequence correspondence to $M$. aeruginosa. The only 3 proteins which did not correspond to $M$. aeruginosa were $\mathrm{m} 10, \mathrm{~m} 18$, and $\mathrm{m} 28$; all of which showed similarities to other cyanobacteria. One spot (m17), identified as superoxide dismutase, was used as a control to increase MS data reliability. Protein identifications showed that $61 \%$ of differential proteins are related to energy metabolism, $18 \%$ corresponded to membrane proteins, $6 \%$ are carboxysome and periplasmic proteins, $12 \%$ are cytoplasmic proteins and 3\% are hypothetical proteins. To avoid double counting, rubisco was considered only in energetic metabolism proteins, although this enzyme is located inside carboxysome. Four of these 21 proteins were found in more than one spot on the gel. Among these are the enzymes Rubisco (spots m01, m02, m11), FBA class II (spots m05, m21), PRK (spots m08, m09, $\mathrm{m} 29$ ), and porins (spots $\mathrm{m} 12, \mathrm{~m} 13, \mathrm{~m} 14, \mathrm{~m} 23$ ) [Table 1].

\section{Energy metabolism proteins}

It is interesting to observe that most of the differentially expressed proteins identified are related to energetic metabolism, and these proteins were up-regulated in the toxin-producing strain. It is important to declare here that we did not estimate the amount of new protein synthesis, but the protein abundance. This increased protein amount can result from higher synthesis (upregulation) and/or stabilization of the identified protein. Ribulose bisphosphate carboxylase (rubisco), glyceraldehyde-3-phosphate dehydrogenase (GAPDH), triosephosphate isomerase, D-fructose 1,6-biphosphatase class II/ sedoheptulose 1,7-biphosphatase (FBPase class II/SBPase) - fructose-1,6-biphosphate aldolase (FBA), phosphoribulokinase (PRK), ferredoxin-NDP ${ }^{+}$oxidoreductase (FNR) were all up-regulated in the toxin-producing strain in comparison with the non-toxin-producing strain [Figure 3a]. Rubisco, GAPDH, PRK and FNR were also observed in thylakoid membrane of Synechocystis sp. PCC 6803 the first time that thylakoid membranes from this cyanobacteria were used in proteomic studies [23]. Rubisco protein appears as isoform in 3 different spots with pI variation in the toxin-producing strain. FBA class II protein also appears in 3 different spots, with pI variation in the toxin-producing strain. However, this protein appears in only two different spots in the non-toxin-producing strain. The same result was observed for the PRK protein, which appears in 3 different spots with pI variation. Nevertheless, the toxin-producing strain presented the same protein at an extra spot, with a molecular mass below that of the other two.

The proteins identified here are all involved in the Calvin cycle, glycolysis and respiration: processes responsible for providing energy to the cell. In the toxinproducing strain, rubisco (m01, m02 e m11), FBPase class II/SBPase (m06, m07 e m22), FBA (m05 e m21) and PRK (m08, m09 e m29) presented relative intensities of expression more than twice those seen in the nontoxin-producing strain. GAPDH (m04) was ten times higher in the toxin-producing strain. FNR was identified only in the toxin-producing strain. Therefore, it is suggested that overexpression of proteins involved in energy production by toxin-producing PCC 7820 probably means a compulsory requirement to produce microcystin, and this production may be synonymous of higher energy consumption. This has already been noted in studies with Streptococcus suis [51], Candida glabrata [52] and Yersinia pestis [53], which showed that expression modifications in metabolic proteins suggest higher virulence. The proteome showed an increase in expression in metabolism-related proteins, like fructose bisphosphate aldolase, glycerol-3-phosphate dehydrogenase and triosephosphate isomerase. According to these authors, an increase in glycolytic metabolism suggests higher virulence. Besides, changes in central carbon metabolism have been associated with virulence attributes and the inactivation of virulence regulators in $C$. albicans [54]. Proteomic results with the bacteria Yersinia pestis virulence indicate that expression changes in metabolic proteins may have a more significant role in virulence than was previously appreciated [53]. In the present study, it also seems that proteins involved in the Calvin cycle, respiration, and glycolysis play important roles related to microcystin production, since the Calvin cycle is the pathway most activated in the toxin-producing $M$. aeruginosa PCC 7820. 
Table 1 Differentially expressed proteins identified from cellular extracts of axenic cultures of $M$. aeruginosa after tryptic digestion and MALDI-TOF/TOF analysis

\begin{tabular}{|c|c|c|c|c|c|c|c|c|c|}
\hline Spot $n$. & Sequence & Accession no & Species & Protein ID & $\begin{array}{l}\text { Sequence } \\
\text { coverage (\%) }\end{array}$ & $\begin{array}{l}\text { Mowse } \\
\text { score }\end{array}$ & Function & $\begin{array}{l}\text { Theoretical } \\
\mathrm{pl} / \mathrm{Mw}(\mathrm{kDa})\end{array}$ & $\begin{array}{l}\text { Experimental } \\
\mathrm{pl} / \mathrm{Mw}(\mathrm{kDa})\end{array}$ \\
\hline \multirow[t]{2}{*}{$\mathrm{m} 01$} & KTFQGPPHGITVERD & \multirow[t]{2}{*}{166367530} & \multirow[t]{2}{*}{ M. aeruginosa } & \multirow{2}{*}{$\begin{array}{l}\text { Ribulose bisophosphate } \\
\text { carboxylase, major subunit }\end{array}$} & \multirow[t]{2}{*}{5.0} & \multirow[t]{2}{*}{82} & \multirow{2}{*}{$\begin{array}{l}\mathrm{CO}_{2} \text { fixation (Calvin cycle) } \\
\text { and photorespiration }\end{array}$} & \multirow[t]{2}{*}{$6.8 / 53.20$} & \multirow[t]{2}{*}{$6.4 / 53.86$} \\
\hline & $\mathrm{G}\|\mathrm{H}\| \mathrm{HR}$ & & & & & & & & \\
\hline \multirow[t]{3}{*}{ m02 } & KTFQGPPHGITVERD & \multirow[t]{3}{*}{166367530} & \multirow[t]{3}{*}{ M. aeruginosa } & \multirow{3}{*}{$\begin{array}{l}\text { Ribulose bisophosphate } \\
\text { carboxylase, major subunit }\end{array}$} & \multirow[t]{3}{*}{9.0} & \multirow[t]{3}{*}{92} & \multirow{3}{*}{$\begin{array}{l}\mathrm{CO}_{2} \text { fixation (Calvin cycle) } \\
\text { and photorespiration }\end{array}$} & \multirow[t]{3}{*}{$6.8 / 53.20$} & \multirow[t]{3}{*}{$6.2 / 53.84$} \\
\hline & AVTMGFVDLMR & & & & & & & & \\
\hline & KTFEGPPHGIQAERD & & & & & & & & \\
\hline \multirow[t]{2}{*}{ m03 } & KIAAEFPDNFRL & \multirow[t]{2}{*}{166363998} & \multirow[t]{2}{*}{ M. aeruginosa } & \multirow{2}{*}{$\begin{array}{l}\text { Ferredoxin-NADP } \\
\text { oxidoreductase }\end{array}$} & \multirow[t]{2}{*}{5.5} & \multirow[t]{2}{*}{44} & \multirow{2}{*}{$\begin{array}{l}\text { Oxidation and reduction } \\
\text { (ficobilissome, thylakoid } \\
\text { membrane) }\end{array}$} & \multirow[t]{2}{*}{$6.1 / 44.81$} & \multirow[t]{2}{*}{$6.9 / 35.61$} \\
\hline & IAAEFPDNFR & & & & & & & & \\
\hline m04 & KGILEYNDLPLVSSDYRG & 166365244 & M. aeruginosa & $\begin{array}{l}\text { Glyceraldehyde-3-phosphate } \\
\text { dehydrogenase }\end{array}$ & 5.3 & 101 & $\begin{array}{l}\text { Glucose metabolic process } \\
\text { (phosphorilation) }\end{array}$ & $6.3 / 36.64$ & $6.6 / 38.49$ \\
\hline \multirow[t]{4}{*}{ m05 } & RKPTGEILAISRI & \multirow[t]{4}{*}{166365988} & M. aeruginosa & Fructose-1,6-bisphosphate & 49 & 74 & Glycolysis & $6.0 / 39.15$ & $5.6 / 43.01$ \\
\hline & YAGENFLRI & & & & & & & & \\
\hline & RKPTGEILAISR & & & & & & & & \\
\hline & KYAGENFLRH & & & & & & & & \\
\hline m06 & KNIADHVAVEAMRE & 166365743 & M. aeruginosa & D-Frutose-1,6-bifosfatase & 10.2 & 78 & Carbohydrate biosynthesis & $4.7 / 37.66$ & $5.1 / 42.99$ \\
\hline & SIEELWWMDRPR & & & $\begin{array}{l}\text { classe I/ sedoneptulose } \\
\text { 1,7-bisfosfatase (FBPase }\end{array}$ & & & (Calvin cycle) & & \\
\hline & FFHGGAR & & & classe 2/SBPase) & & & & & \\
\hline m07 & LQEMGITNPDR & 166365743 & M. aeruginosa & D-Frutose-1,6-bifosfatase & 6.7 & 59 & Carbohydrate biosynthesis & $4.37 / 37.12$ & 4.95 / 43.12 \\
\hline & FVDTVHLFDQPK & & & $\begin{array}{l}\text { 1,7-bisfosfatase (FBPase } \\
\text { classe 2/SBPase) }\end{array}$ & & & & & \\
\hline m08 & RKPDFSAYIDPQRQ & 159027237 & M. aeruginosa & Phosphoribulokinase (PRK) & 18.0 & 107 & Carbohydrate metabolic process & $5.45 / 38.04$ & $5.00 / 40.88$ \\
\hline & KVIVIEGLHPLYDERV & & & & & & & & \\
\hline & RKPDFSAYIDPQRQ & & & & & & & & \\
\hline & KVIVIEGLHPLYDERV & & & & & & & & \\
\hline m09 & RKPDFSAYIDPQRQ & 159027237 & M. aeruginosa & Phosphoribulokinase (PRK) & 27.3 & 112 & Carbohydrate metabolic process & $5.45 / 38.03$ & $4.86 / 40.77$ \\
\hline & KVIVIEGLHPLYDERV & & & & & & & & \\
\hline & RGHTYDDVMAAINSRK & & & & & & & & \\
\hline & RKPDFSAYIDPQRQ & & & & & & & & \\
\hline & KVIVIEGLHPLYDERV & & & & & & & & \\
\hline & VLSVLLGMTIGQ\|HR & & & & & & & & \\
\hline m10 & TLPDLIHSAPR & 196257787 & Cyanothece sp. & $\begin{array}{l}\text { FAD-dependent pyridine } \\
\text { nucleotide-disulphide } \\
\text { oxidoreductase }\end{array}$ & 2.6 & 25 & Oxidoreductase & $6.41 / 46.87$ & $8.41 / 42.98$ \\
\hline m11 & KTFQGPPHGITVERD & 166367530 & M. aeruginosa & & 10.6 & 91 & & $6.76 / 53.20$ & $6.57 / 54.67$ \\
\hline
\end{tabular}


Table 1 Differentially expressed proteins identified from cellular extracts of axenic cultures of $M$. aeruginosa after tryptic digestion and MALDI-TOF/TOF analysis (Continued)

\begin{tabular}{|c|c|c|c|c|c|c|c|c|c|}
\hline & RGITMGFVDLMRE & & & ribulose bisophosphate & & & $\mathrm{CO}_{2}$ fixation (Calvin cycle) & & \\
\hline & KNHGIHFRV & & & & & & and photorespiration & & \\
\hline & TFQGPPHGITVER & & & & & & & & \\
\hline \multirow[t]{6}{*}{$\mathrm{m} 12$} & RDNDVTIDDLFYRA & \multirow[t]{6}{*}{166365540} & \multirow[t]{6}{*}{ M. aeruginosa } & \multirow{6}{*}{$\begin{array}{l}\text { Porin type major outer } \\
\text { membrane protein }\end{array}$} & \multirow[t]{6}{*}{15.7} & \multirow[t]{6}{*}{106} & \multirow{6}{*}{$\begin{array}{l}\text { Transport (integral } \\
\text { membrane protein) }\end{array}$} & \multirow[t]{6}{*}{4.14 / 60.14} & \multirow[t]{6}{*}{$4.78 / 50.13$} \\
\hline & KFADINFVYRS & & & & & & & & \\
\hline & RLQAGNFNNTFNQSGPTRT & & & & & & & & \\
\hline & KFADINFWVRS & & & & & & & & \\
\hline & LQAGNFNNTFNQSGPTR & & & & & & & & \\
\hline & QSQTPAHQSRANQR & & & & & & & & \\
\hline \multirow[t]{4}{*}{$\mathrm{m} 13$} & RDNDVTIDDLFYRA & \multirow[t]{4}{*}{166365540} & \multirow[t]{4}{*}{ M. aeruginosa } & \multirow{4}{*}{$\begin{array}{l}\text { Porin type major outer } \\
\text { membrane protein }\end{array}$} & \multirow[t]{4}{*}{10.4} & \multirow[t]{4}{*}{96} & \multirow{4}{*}{$\begin{array}{l}\text { Transport (integral } \\
\text { membrane protein) }\end{array}$} & \multirow[t]{4}{*}{$4.14 / 60.14$} & \multirow[t]{4}{*}{$4.64 / 50.1$} \\
\hline & LQAGNFNNTFNQSGPTR & & & & & & & & \\
\hline & RDVSPTAWAYEALRS & & & & & & & & \\
\hline & KFADINFVIRS & & & & & & & & \\
\hline \multirow[t]{3}{*}{$\mathrm{m} 14$} & LQAGNFNNTFNQSGPTR & \multirow[t]{3}{*}{166365540} & \multirow[t]{3}{*}{ M. aeruginosa } & \multirow{3}{*}{$\begin{array}{l}\text { Porin type major outer } \\
\text { membrane protein }\end{array}$} & \multirow[t]{3}{*}{8.6} & \multirow[t]{3}{*}{84} & \multirow{3}{*}{$\begin{array}{l}\text { Transport (integral } \\
\text { membrane protein) }\end{array}$} & \multirow[t]{3}{*}{4.14 / 60.14} & \multirow[t]{3}{*}{$4.48 / 50.43$} \\
\hline & KFADINFVYRS & & & & & & & & \\
\hline & RLQAGNFNNTFNQSGPTRT & & & & & & & & \\
\hline \multirow[t]{2}{*}{$\mathrm{m} 15$} & RGWINDINETQNTTVNYPIIADGDRK & \multirow[t]{2}{*}{166366392} & M. aeruginosa & Peroxiredoxin & 19.4 & 180 & Cell redox homeostasis & $4.17 / 16.55$ & $4.68 / 25.39$ \\
\hline & KVIALSVDSAESHRG & & & & & & & & \\
\hline $\mathrm{m} 16$ & QYFGETDETVNLR & 166363870 & M. aeruginosa & Triosephosphate isomerase & 12.2 & 62 & Triosephosphate isomerase & 4.14 / 25.21 & $4.85 / 27.01$ \\
\hline & RQYFGETDETVNLRV & & & & & & $\begin{array}{l}\text { activity (glyconeogenesis } \\
\text { and glycolysis) }\end{array}$ & & \\
\hline $\mathrm{m} 17$ & RPDYISDFLTK & 166368140 & M. aeruginosa & Superoxide dismutase (SOD) & 9.0 & 40 & Catalyzes of superoxide to & $5.83 / 21.72$ & $4.6 / 21.50$ \\
\hline & YLDYQNR & & & & & & $\begin{array}{l}\text { peroxide and molecular } \\
\text { oxygen }\end{array}$ & & \\
\hline $\mathrm{m} 18$ & IVQASTGLEVLSDSILVQKLR & 220908731 & Cyanothece & $\mathrm{ABC}$ transport related & 5.8 & 78 & Stress response & $6.07 / 64.52$ & $4.99 / 18.61$ \\
\hline & FLIATPLLLALMR & & sp. PC & & & & & & \\
\hline $\mathrm{m} 19$ & RLITYGWAGDVTPIEEIGLVGVRE & 166363768 & M. aeruginosa & Allophycocyanin alpha subunit & 25.5 & 104 & Photosynthesis & $4.21 / 17.19$ & $3.79 / 18.09$ \\
\hline & YLSPGELDR & & & & & & (priycodilsome) & & \\
\hline & DMDYYLR & & & & & & & & \\
\hline $\mathrm{m} 20$ & RVPAEIVFDQGLGDLFVCRV & 166364254 & M. aeruginosa & $\begin{array}{l}\text { Carbonic anhydrase, beta-type } \\
\text { (CA) }\end{array}$ & 8.3 & 130 & Carbon utilization & $8.45 / 26.10$ & $7.50 / 21.93$ \\
\hline $\mathrm{m} 21$ & KYAGENFLRH & 166365988 & M. aeruginosa & Fructose-1,6-bisphosphate & 10.0 & 59 & Glycolysis & $6.00 / 39.16$ & $5.39 / 43.1$ \\
\hline & RKPTGEILAISRI & & & & & & & & \\
\hline
\end{tabular}


Table 1 Differentially expressed proteins identified from cellular extracts of axenic cultures of $M$. aeruginosa after tryptic digestion and MALDI-TOF/TOF analysis (Continued)

\begin{tabular}{|c|c|c|c|c|c|c|c|c|c|}
\hline \multirow[t]{4}{*}{$\overline{\mathrm{m} 22}$} & RSIEELWWMDRPRH & \multirow[t]{4}{*}{166365743} & \multirow[t]{4}{*}{ M. aeruginosa } & \multirow{4}{*}{$\begin{array}{l}\text { D-fructose 1,6- bisphosphatase } \\
\text { class 2/sedoheptulose 1,7- } \\
\text { bisphosphatase (FBPase } \\
\text { classe 2/SBPase) }\end{array}$} & \multirow[t]{4}{*}{14.2} & \multirow[t]{4}{*}{67} & \multirow{4}{*}{$\begin{array}{l}\text { Carbohydrate biosynthesis } \\
\text { (Calvin cycle) }\end{array}$} & \multirow[t]{4}{*}{$4.37 / 37.68$} & \multirow[t]{4}{*}{$4.95 / 45.86$} \\
\hline & FFHGGAR & & & & & & & & \\
\hline & FVDTVHLFDQPK & & & & & & & & \\
\hline & RFVDTVHLFDQPKY & & & & & & & & \\
\hline \multirow[t]{2}{*}{ m23 } & DVSPTAWAYEALR & \multirow[t]{2}{*}{166365540} & \multirow[t]{2}{*}{ M. aeruginosa } & \multirow{2}{*}{$\begin{array}{l}\text { Porin type major outer } \\
\text { membrane protein }\end{array}$} & \multirow[t]{2}{*}{4.6} & \multirow[t]{2}{*}{45} & \multirow{2}{*}{$\begin{array}{l}\text { Transport (integral } \\
\text { membrane protein) }\end{array}$} & \multirow[t]{2}{*}{$4.14 / 60.14$} & \multirow[t]{2}{*}{$3.94 / 57.46$} \\
\hline & DVERALTAPHLTR & & & & & & & & \\
\hline \multirow[t]{2}{*}{ m24 } & RQYFGETDETVNLRV & \multirow[t]{2}{*}{166363870} & \multirow[t]{2}{*}{ M. aeruginosa } & \multirow[t]{2}{*}{ Triosephosphate isomerase } & \multirow[t]{2}{*}{6.5} & \multirow[t]{2}{*}{62} & \multirow{2}{*}{$\begin{array}{l}\text { Triosephosphate isomerase } \\
\text { activity (gluconeogenesis } \\
\text { and glycolysis) }\end{array}$} & \multirow[t]{2}{*}{$4.14 / 25.21$} & \multirow[t]{2}{*}{$4.85 / 27.01$} \\
\hline & RQYFGETDETVNLRV & & & & & & & & \\
\hline \multirow[t]{2}{*}{ m25 } & RTFTEVAPQPAPEPSVSPIRG & \multirow[t]{2}{*}{166367494} & \multirow[t]{2}{*}{ M. aeruginosa } & \multirow{2}{*}{$\begin{array}{l}\text { Hypothetical protein } \\
\text { MAE_ } 47530\end{array}$} & \multirow[t]{2}{*}{30.8} & \multirow[t]{2}{*}{69} & \multirow[t]{2}{*}{ Non function related } & \multirow[t]{2}{*}{$5.32 / 13.01$} & $8.39 / 17.08$ \\
\hline & RGEPQLNPGDYLGRV & & & & & & & & \\
\hline $\mathrm{m} 26$ & RAPYDESEWYHLDLYENKG & 159029497 & M. aeruginosa & Phycobilisome rod linker & 2.1 & 119 & Photosynthesis & $9.24 / 32.21$ & $5.51 / 29.88$ \\
\hline & FQQCLVQTR & & & & & & & & \\
\hline & RETPVMSQAEIHSR & & & & & & & & \\
\hline m27 & LVSLGLLK & 159028959 & M. aeruginosa & $\begin{array}{l}\text { Cobalt } A B C \text { transporter, inner } \\
\text { membrane subunit CbiQ }\end{array}$ & 3.1 & 72 & $\begin{array}{l}\text { Cobalt trasnport and } \\
\text { biosynthetic process of } \\
\text { cobalamin }\end{array}$ & $10.22 / 28.53$ & $5.18 / 37.08$ \\
\hline $\mathrm{m} 28$ & KKILLLLVLIVAVLNFGKT & 15642898 & T. maritima & $\begin{array}{l}\text { Zinc ABC transporter, } \\
\text { periplasmic } \\
\text { zinc-binding protein }\end{array}$ & 7.1 & 61 & Metal transport & $6.25 / 30.12$ & $4.85 / 52.85$ \\
\hline m29 & KPDFSAYIDPQR & 166366586 & M. aeruginosa & Phosphoribulokinase (PRK) & 3.6 & 42 & Kinase and transferase & $5.12 / 37.85$ & $4.42 / 36.73$ \\
\hline & & & & & & & ATP binding & & \\
\hline m30 & QAGSIVCISSISGDR & 166367746 & M. aeruginosa & $\begin{array}{l}\text { PHA-specific acetoacetyl-CoA } \\
\text { reductase }\end{array}$ & 6.3 & 49 & Oxidoreductase & $5.66 / 25.18$ & $5.89 / 27.19$ \\
\hline
\end{tabular}



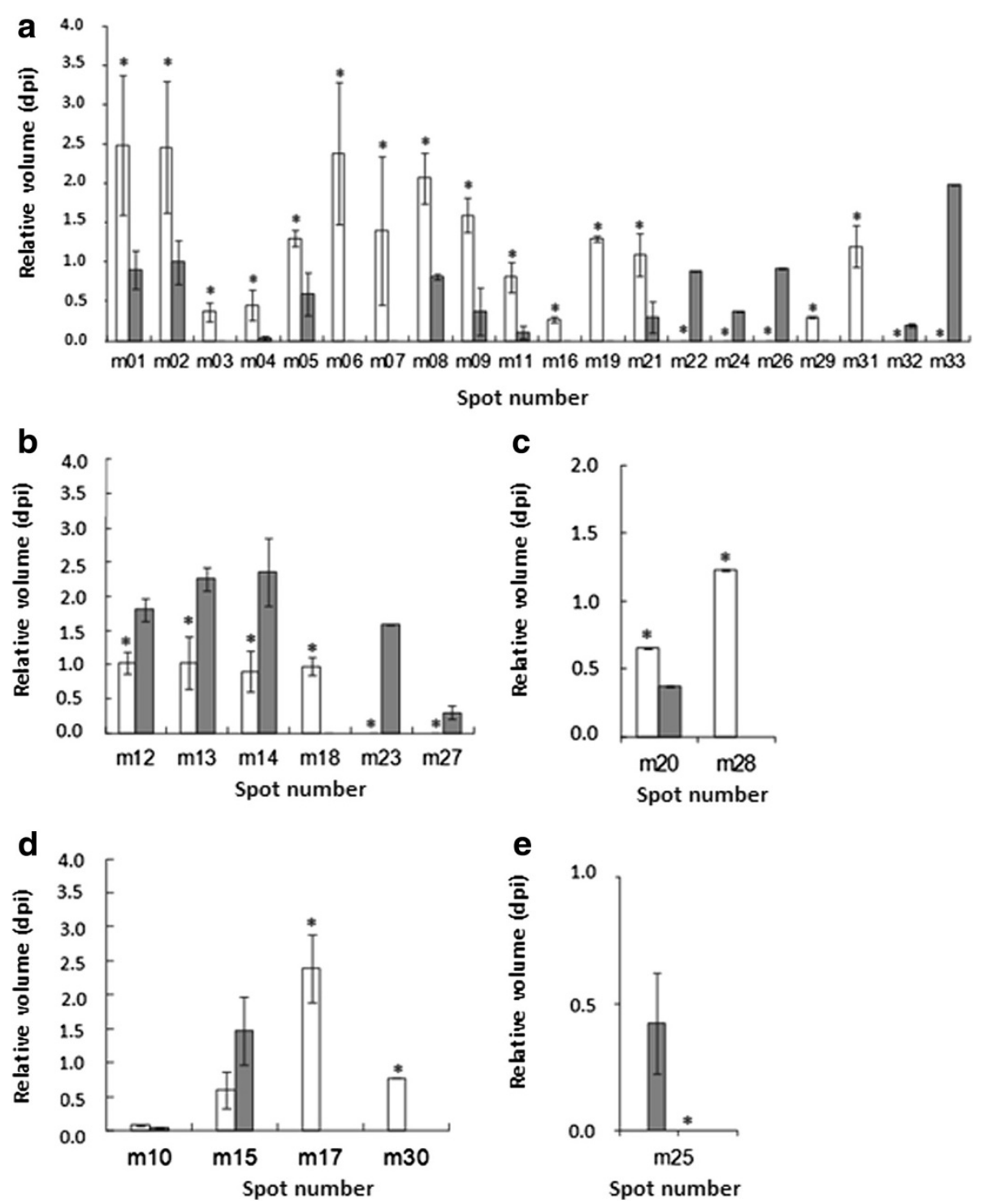

Figure 3 Differentially expressed proteins obtained from 2D gels of $M$. aeruginosa PCC 7820 (white) and NIVA CYA 43 (grey) strains related to (a) energy metabolism; (b) membrane proteins (external and internal); (c) periplasmic proteins; (d) cytoplasmic proteins and (e) hypothetical proteins. Vertical bars correspond to standard deviation. The asterisks indicate protein expression that differed significantly $(p<0.05)$ between the toxin producing (PCC 7820) and non-toxin producing (NIVA CYA 43) strains by the Student's t-test.

\section{Carboxysome and periplasmic proteins}

Carbonic anhydrase (CA) and a protein with high sequence similarity to zinc $\mathrm{ABC}$ transporter of Thermotoga maritima MSB8 were identified and both were upregulated by the toxin-producing strain [Figure $3 \mathrm{c}$ and Table 1]. The up-regulation of CA may occurs at the same time as the expression of zinc $A B C$ transporter at the toxin-producing strain, since zinc is a metal required for the active site of $\mathrm{CA}$, where this metal has a central role in carbon fixation for photosynthesis [55].

These results are in accordance with observations about energy metabolism proteins. $\mathrm{CA}$ is an enzyme that participates in the $\mathrm{CO}_{2}$ concentrate mechanism (CCM). In aquatic environments with $\mathrm{pH}$ values above 7 , inorganic carbon is available preferably in the form of carbonic acid $\left(\mathrm{HCO}_{3}^{-}\right)$[56]. Therefore, aquatic photosynthetic microorganisms developed CCM to generate an intracellular pool of inorganic carbon.

Data reported here shows that CA was expressed by the toxin-producing PCC 7820 [Figure 3c], 1.8 times stronger than the non-toxin-producing strain. Probably, the toxin-producing strain has an improvement of carbon fixation. This improvement could be directly related to microcystin production, since the use of carbons and 
energy was necessary in this process. Moreover, this result could also be related to an increase of metabolic flux through the Calvin cycle, mentioned above. In both cases, this reflects a more efficient carbon fixation that leads to PHA accumulation. With a higher quantity of carbon, it may be possible to maintain an efficient microcystin production.

\section{Cytoplasmic proteins}

The identified protein in spot $\mathrm{m} 10$ presented a high similarity with an enzyme from the flavoprotein family: a FAD-dependent pyridine nucleotide-disulphide oxidoreductase, present in Cyanothece sp. This enzyme acts in cellular redox homeostasis processes and oxidation and reduction, where its molecular function is to carry out the activities of oxidoreductase and the electron carrier. Co-factors iron $(\mathrm{Fe})$ and sulfur $(\mathrm{S})$ are necessary for its action [57]. Flavoproteins seem to play an important role in bloom situations since they are frequently found in cyanobacteria collected from dense blooms. In environments with dense blooms, Fe and copper deficiency often occurs [57]. Flavoproteins have the capacity to substitute ferredoxins in some cyanobacteria when they lack $\mathrm{Fe}$, because these two protein classes are similar in relation to charge set and redox properties [58]. This protein was expressed by both strains at similar statistical levels [Figure 3d] suggesting that both cyanobacteria may naturally have this advantage. Therefore, their growth may be favored in these environments, but toxin production may not necessarily be favored.

Peroxiredoxin (m15), observed only in the M. aeruginosa PCC 7820 gel, presents physiological significance as anti-oxidative stress in cyanobacteria [59]. This enzyme catalyzes the reduction of various hydroperoxides [60] and seems not to be related to microcystin production. Otherwise, the tryptic fragments of protein spot $\mathrm{m} 17$ were identified as superoxide dismutase, an enzyme that protects the cell against damage caused by superoxide radicals [61].

The PHA-specific enzyme acetoacetyl-CoA reductase (m30) was exclusive to the toxin-producing strain. In Synechocystis sp. PCC 6803, this protein has the function of PHA (polyhydroxyalkanoate) accumulation in the cell and, together with ketothiolase- $\beta$ PHA specific enzyme, forms the first complete PHA biosynthesis route known in cyanobacteria [62]. PHAs are biodegradable polyesters, carbon and energy storage compounds, which are deposited as insoluble inclusions at cytoplasm [62]. The fact that this protein appeared only in the toxin-producingstrain indicates that to maintain the state of microcystin producer, $M$. aeruginosa PCC 7820 must have access to energy reserves. It may be considered that, since the toxin-producing strain has higher expression levels of proteins related to energy metabolism in relation to the non-toxin-producing strain, there is a need to produce proteins required for intracellular accumulation of energy produced. The expression of this enzyme only by the toxin-producing stain suggests that producing microcystin means that more energy is spent due to the carbon and energy accumulation need seen in toxin-producing M. aeruginosa PCC 7820.

\section{Membrane proteins}

In this work, 4 spots were identified as external membrane porins. The porin protein appears in 4 different spots on the non-toxin-producing strain gel, with 3 isoforms and another spot with pI and MW different from the other three. Surprisingly, spots $\mathrm{m} 12, \mathrm{~m} 13$ and $\mathrm{m} 14$ were about twice as highly expressed in the non-toxin-producing in relation to the toxin-producing strain and spot $\mathrm{m} 23$ was exclusive to the non-toxin-producing strain [Figure 3b]. This observation represents an inversion of what has been seen for the other protein classes, and no toxin relation has been drawn until now. However, higher expression of porin in the non-toxin-producing strain seems to be in accordance with higher expression of peroxiredoxin. In relation to phycobilisome proteins, we identified allophycocyanin alpha subunit (m19) only in the toxin-producing strain, phycobilisome rod linker polypeptide (m26) and phycocyanin alpha phycocyanobilin lyase related protein (m32), of which the last three only appear in the non-toxin-producing strain.

Spot m18 appeared only in the toxin-producing strain [Figure $3 \mathrm{~b}$ ] and presented high sequence similarity with an $\mathrm{ABC}$ transporter of Cyanothece sp. $\mathrm{PCC}$ 7425. ABC transporters are a family of membrane proteins that carry out the transport of molecules rather than ions, and are involved in several physiological processes [63].

Otherwise, the $\mathrm{ABC}$ transporter was considered as a stress-related protein [36, 64]. In Spirulina platensis, this protein was detected in all subcellular fractions up-regulated when this cyanobacterium was submitted to hightemperature [64] and to low-temperature stresses [36] and its transcriptional expression pattern was well correlated with the protein expression pattern.

Then, Amnuaykanjanasin and Daub [65] recently observed that the fungal Cercospora nicotianae disrupted at the $\mathrm{ABC}$ transporter gene (atr1) shows a dramatic reduction in the production of the toxin cercosporin. These data [65] indicate that qualitative and quantitative differential expression of proteins in the mycelium provides evidence to partly explain the mechanism of pathogen virulence differentiation. Similarly, our results indicate that the toxin-producing $M$. aeruginosa PCC 7820 presents higher synthesis of proteins involved in metabolism in relation to the non-toxin-producing M. aeruginosa NIVA CYA 43. 


\section{Conclusions}

It have been observed that microcystin production provides a photosynthetic and ecological advantage adjusting rubisco synthesis [66], participation in processes associated with light reactions [67] and predation inhibition [68,69]. Putative functions of microcystin should result in a competitive advantage for those strains that are able to produce it. Therefore, microcystin nontoxin-producing strains need to develop compensating mechanisms. According Meißner et al. [70], non-toxic strains have genes coding for proteins involved in toxin production (peptide synthetases). Nevertheless, those strains seem to produce fewer gene copies in relation to toxics trains, mostly differing by genes content. Data reported here show that toxic strains are capable of producing proteins involved in energy metabolism at a higher quantity than nontoxic strains. However, in competition experiments, it was shown that nontoxic strains are better competitors for light than toxic strains [71]. These authors also suggest that non-toxic strains may invest their resources in other cellular functions since they are unable to utilize energy to produce microcystin. Our results point in same direction. Nontoxic strains probably have compensating mechanisms, using energy not spent in microcystin production in multiple cellular functions, like higher porin production and also in the improvement of cell size. Data reported here suggest a dualistic response: either microcystin stimulates the production of metabolism-related proteins or else metabolism proteins are expressed in higher quantities that enable the cell's microcystin synthesis. In summary, energetic metabolism proteins (Calvin cycle, glycolysis and respiration) were observed, being expressed in larger amounts by the toxin-producing strain ( $M$. aeruginosa PCC 7820). Corroborating these data, the expressions of other proteins that depend on energy production, which includes proteins related to carbon and nitrogen accumulations forming a kind of strategic cellular reservoir for eventual nutrient starvation, were also obtained. In an overview, the energy improvement observed in toxin production may provide a continuity of microcystin production under different environmental conditions. Additionally, the same proteins involved in stress response also seem to be linked to microcystin production, which included the $\mathrm{ABC}$ transporters and as well as the peroxiredoxin forms. This information leads to suggest the idea that an improvement of carbon and nitrogen fixation is necessary in the first moment. This modification may lead, in the next moment, to a higher ATP synthesis [Figure 4]. In parallel, the necessity of a stress response signal was also observed, correlated with the enhanced expression of cytoplasmic and membrane proteins. These processes together seem to orchestrate part of the microcystin synthesis process. Moreover, it is very interesting to notice that the Microcystis-cell machinery may work in a complex and harmonious manner, having the modulation of several proteins involved in microcystin production. Despite findings in energy metabolism and stress response provided here, it is also important to be clear that other processes could also be involved in cyanotoxin production that were not detected here by proteomic techniques. Another important issue is that we do not know at the moment if the non-toxin producer has the microcystin synthetase (mcy) genes that encode specific peptide synthetases, which have been shown to be involved in the construction of the toxic peptides. Nevertheless, studies performed by Cristiansen et al. [72] showed that gene cluster deletion is a rare event in nontoxic cyanobacteria. These modifications associated with the evolutionary diversification of the strain lineages lead to a combination of cyanobacteria that either lost or still contain the mcy-gene cluster in the same environment. Overall, proteomics technology may be considered a powerful tool used for uncovering the nature of microcystin production and its regulation in function of environmental changes. This understanding may significantly contribute to the development of compounds which may be employed directly in the environment, aiming to block microcystin production by a toxin-pathway-specific means, thus preventing its release into water.

\section{Methods}

\section{Organisms and culture conditions}

M. aeruginosa PCC 7820 and M. aeruginosa NIVA CYA 43 were acquired from CSIRO (Commonwealth Scientific and Industrial Research Organization), Australia, and grown in a modified MLA medium $\left(\mathrm{MgSO}_{4} \cdot 7 \mathrm{H}_{2} \mathrm{O}\right.$ $200 \mathrm{mM}, \mathrm{NaNO}_{3} 1 \mathrm{M}, \mathrm{K}_{2} \mathrm{HPO}_{4} 40 \mathrm{mM}, \mathrm{H}_{3} \mathrm{BO}_{3} 40 \mathrm{mM}$, $\mathrm{NaHCO}_{3} 200 \mathrm{mM}, \mathrm{CaCl}_{2} \cdot 2 \mathrm{H}_{2} \mathrm{O} 200 \mathrm{mM}$, vitamins and micronutrients, $\mathrm{pH}=7.5$ ) in $1000 \mathrm{~mL}$ Erlenmeyer flasks (800 mL liquid). The cultures were maintained at $22^{\circ} \mathrm{C}$ under a 12:12 h light/dark cycle and illuminated with $6 \mu \mathrm{mol}$ of photons. $\mathrm{m}^{-2} \cdot \mathrm{s}^{-1}$ of fluorescent white light. Cells were harvested from the growth medium at late exponential phase $\left(\mathrm{OD}_{680 \mathrm{~nm}}=0.7-\right.$ for $M$. aeruginosa PCC 7820, and $\mathrm{OD}_{680 \mathrm{~nm}}=0.8-$ for $M$. aeruginosa NIVA CYA 43). The growth profile of $M$. aeruginosa was conducted in order to determine the end of the exponential phase. The growth curve was determined in 25 days, and the OD evaluation was conducted simultaneously every three days during this period. All measurements were done in triplicate at three different ODs: $680 \mathrm{~nm}$, $730 \mathrm{~nm}$ and $750 \mathrm{~nm}$ for each sample, considering wave length absorbed by cyanobacterial pigments, such as chlorophyll and bilins. These three different ODs were used to verify the correspondence between growth curves obtained by these different wave lengths and if 


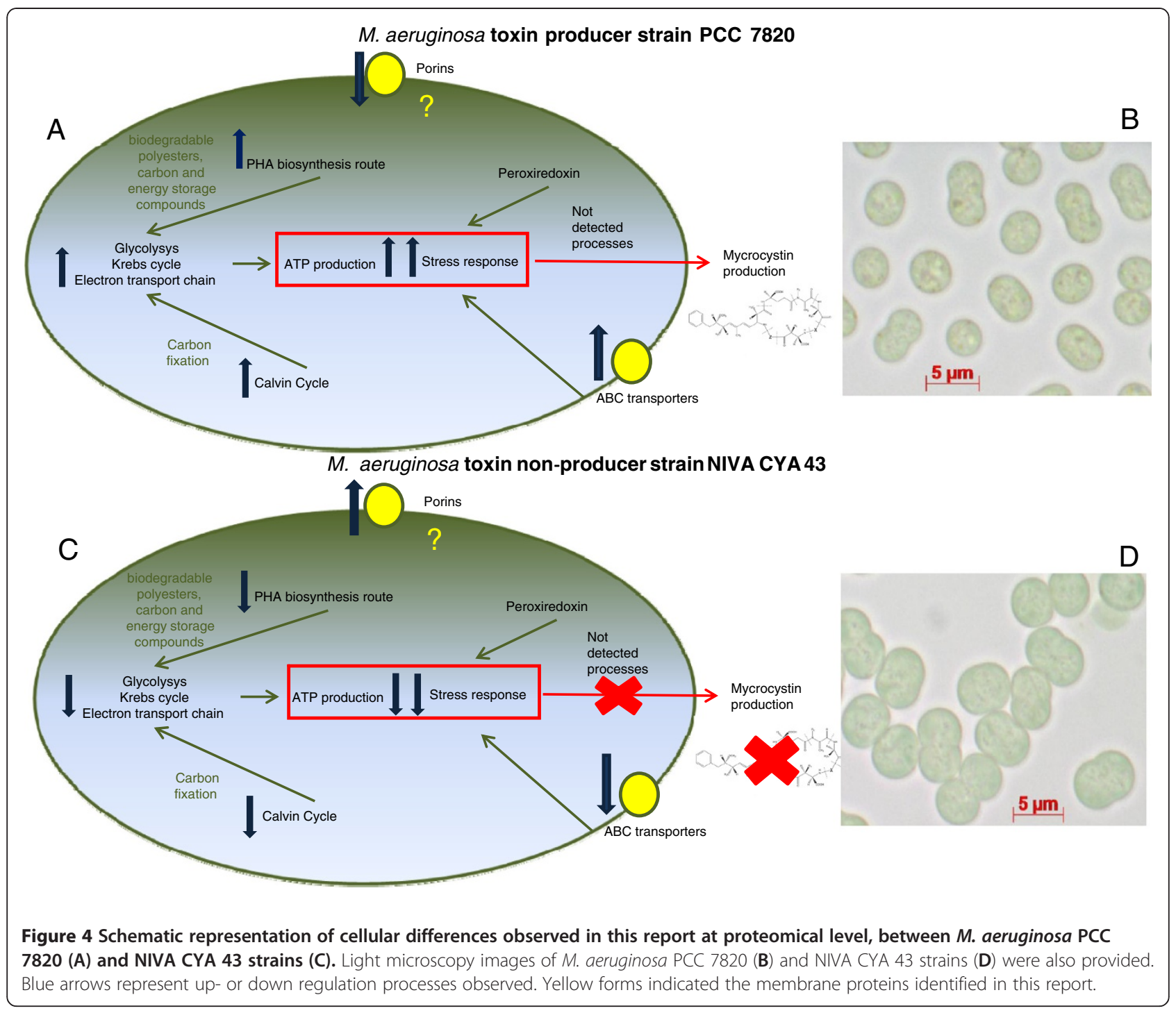

both strains grew equally well. For cell extraction, $\mathrm{OD}_{680 \mathrm{~nm}}$ was used to track cell growth. Although there were slight differences, correspondence between curves was shown regardless of the wavelength used (Additional file 1: Figure S1). For protein extraction, cultures of $M$. aeruginosa PCC 7820 and NIVA CYA 43 were centrifuged at $\mathrm{OD}_{680 \mathrm{~nm}}=0.7$ and $\mathrm{OD}_{680 \mathrm{~nm}}=0.8$, respectively, corresponding to the end of log phase.

\section{Microcystin detection}

During $\log$ phase, $1 \mathrm{~mL}$ aliquots of each strain were collected for evaluation. These aliquots were ground under liquid nitrogen (five times) followed by pelleting of insoluble debris by centrifugation at 12,100 g for $5 \mathrm{~min}$. Protein concentration was determined by Qubit ${ }^{\mathrm{m}}$ Fluorometer (Invitrogen, Oregon, USA). Each aliquot was separately analyzed on a reversed-phase C-18 HPLC (GE Healthcare) column (Vydac 218 PT $5 \mu \mathrm{m}$ pore), at flow of $1 \mathrm{~mL} \cdot \mathrm{min}^{-1}$. This was run for $35 \mathrm{~min}$ and followed by a non-linear acetonitrile gradient (35\% to $95 \%$ ), using TFA $0.1 \%$ as ion pairing, according to Harada et al. [73] with modifications. The absorbance was monitored at $238 \mathrm{~nm}$. The collected fractions were dried in speed vacuum (Labconco). Fraction analyses were conducted in a MALDI-TOF/TOF Ultraflex III (Bruker Daltonics). The chromatography fractions were resuspended in $20 \mu \mathrm{L}$ TFA $0.1 \%$ and mixed in a $1: 3 \mathrm{v} / \mathrm{v}$ proportion with a saturated solution of $\alpha$-cyano-4-hydroxycinnamic acid matrix. From this mixture, $1 \mu \mathrm{L}$ was manually spotted onto a MALDI target plate. The spectra were acquired in positive reflector mode. Ions with enough intensity were selected for cleavage by MS/MS. Microcystin fragmentation standard was generated by LIFT mode with external calibration using Peptide Calibration Standard II (Bruker). 
Protein extraction and two-dimensional gel electrophoresis Cells were harvested by centrifugation $(3,000 \mathrm{~g}$ for $30 \mathrm{~min}$ at $4^{\circ} \mathrm{C}$ ) and mixed in buffer extraction $(5 \mathrm{mM}$ Tris $-\mathrm{HCl}$ containing $5 \mathrm{mM} \mathrm{CaCl} 2.2 \mathrm{H}_{2} \mathrm{O}, 0.01 \%$ triton-X-100 and $1 \mathrm{mM}$ proteinase inhibitor cocktail (GE Healthcare)), followed by grinding under liquid nitrogen (five times) and pelleting of the insoluble debris by centrifugation at $3,000 \mathrm{~g}$ for $30 \mathrm{~min}$ at $4^{\circ} \mathrm{C}$. The protein concentration was determined using Qubit ${ }^{\mathrm{TM}}$ Fluorometer (Invitrogen, Oregon, USA) according to the manufacturer's instructions. 2-DE was performed with $13 \mathrm{~cm}$ gels with a 3-11 $\mathrm{pH}$ range loaded with $600 \mu \mathrm{g}$ of protein. Prior to electrophoresis, protein samples (biological triplicate for each strain) were TCA precipitated Pellets were washed three times with $100 \%$ cold acetone and cleaned with 2-DE cleaningup kit (GE Healthcare), as indicated by the manufacturer. Precipitate was solubilized in $250 \mu \mathrm{L}$ of an electrofocusing solution containing $8 \mathrm{M}$ urea, $2 \mathrm{M}$ thiourea, 2\% (v/v) CHAPS, 1\% (v/v) IPG buffer 3-10, 65 mM DTT and traces of bromophenol blue. Strips were rehydrated in this solution overnight at $20^{\circ} \mathrm{C}$. The isoelectric focusing of the proteins was performed on an IPGphor (GE Healthcare), and the running conditions were (i) $500 \mathrm{~V}$ for $1 \mathrm{~h}$; (ii) $1000 \mathrm{~V}$ for $2 \mathrm{~h}$; (iii) $3500 \mathrm{~V}$ for $5 \mathrm{~h} 30 \mathrm{~m}$ and (iv) $3500 \mathrm{~V}$ for $10 \mathrm{~h}$ until a total of 40,000 Vh. The gel strips were then incubated in equilibrated buffer (Tris- $\mathrm{HCl} 1.5 \mathrm{M}, 6 \mathrm{M}$ urea, $30 \%$ (v/v) glycerol, 2\% SDS, 1\% DTT, 1\% iodoacetamide and traces of bromophenol blue) for $30 \mathrm{~min}$ before being pointed at the top of a $12.5 \%$ polyacrylamide gel and sealed with $0.5 \%$ agarose. Electrophoresis was carried out at $15^{\circ} \mathrm{C}$ and $67 \mathrm{~mA} /$ gel for $8 \mathrm{~h}$. Proteins were detected by Coomassie Blue G-250, scanned using an image scanner (HP scanner Scanjet 8290) and evaluated with the BioNumerics software 4.6 version (Applied Maths NV, Belgium) as described below.

\section{Image analysis}

A total of five gel replicates for each strain (M. aeruginosa PCC 7820 and M. aeruginosa NIVA CYA 43) were selected and submitted to in silico analysis by BioNumerics 5.1 software (Applied Maths). 16-bit TIFF gel image replicates (gray scale and $600 \mathrm{dpi}$ ) were aligned and screened by the software in order to detect the protein spots and determinate their concentration, molecular weight $(\mathrm{Mw})$ and isoelectric point $(\mathrm{pI})$. Afterward, gel images of all strains were intercrossed and screened for spot differences and similarities. Statistic correlation analysis $\left(\mathrm{R}^{2}\right)$ was applied to evaluate differential gel data. Correlations cut offs were applied and gels with $\mathrm{R}^{2}$ lower than 0.7 were discarded. Mean value of spot volume (dpi) from spot densities was used for further comparison of protein expression, taking into account spots with relative volume equal to or bigger than 0.1 dpi. Moreover, the toxin-producing cyanobacterial protein spots were considered differentially expressed when present/absent in all replicates; when at least twofold changed (up or down) compared to control (nontoxin-producing strain); when the standard deviation bars did not intercross. Finally, all spots that achieved the minimum requires were submitted to Student's $t$-test and differences with $p<0.05$ were considered significant.

\section{In-gel digestion and MALDI-TOF analysis}

In-gel digestion, including reduction with DTT and alkylation with iodoacetamide, was performed according to Schevchenko et al. [74], with minor modifications, using $600 \mathrm{ng}$ of trypsin gold-mass spectrometry grade (Promega) per spot and digested for $24 \mathrm{~h}$ at $37^{\circ} \mathrm{C}$. The samples were air dried, resuspended in $10 \mu \mathrm{L}$ of milli-Q water and analyzed in a MALDI-TOF/TOF Ultraflex III (Bruker Daltonics). One $\mu \mathrm{L}$ of each digest was mixed with $3 \mu \mathrm{L}$ of a saturated solution of $\alpha$-cyano-4hydroxycinnamic acid matrix and was manually spotted onto a MALDI target plate. The spectra were acquired in positive reflector mode with 200 random shoots. Ions with enough intensity were selected for cleavage by MS/MS. Fragmentation standard was generated by LIFT mode with external calibration, performed using Peptide Calibration Standard II (Bruker) with accuracy of 0.3 Da.

\section{Database search}

Proteins were identified by using the MASCOT search engine (Matrix Science, London, UK) using the NCBInr database. The search parameters included carbamidomethylation of cysteines, oxidation of methionines, one miscleavage by trypsin and $80 \mathrm{ppm}$ mass accuracy. The identification of the proteins was repeated at least once using spots from different gels. Identifications with probability based on Mowse Scores $\geq 50$ were considered significant $(\mathrm{P}<0.05)$, and identifications with Mowse Score $<50$ were then disregarded.

\section{Additional files}

Additional file 1: Figure S1. Growth curves of M. aeruginosa PCC 7820 (a) and M. aeruginosa NIVA CYA 43 (b). Cyanobacteria development was evaluated at wavelength of $680 \mathrm{~nm}, 730 \mathrm{~nm}$ and $750 \mathrm{~nm}$. Black arrows correspond to the end of log phase in which protein extraction occurs.

Additional file 2: Figure S2. SDS-PAGE 15\% by using crude protein cytosolic extract $\left(50 \mu \mathrm{g} \cdot \mathrm{ml}^{-1}\right)$ from $M$. aeruginosa samples. (a) corresponds to $M$. aeruginosa PCC 7820 and (b) corresponds to M. aeruginosa NIVA CYA 43. Gel was Coomassie stained. M corresponds to molecular mass.

\section{Abbreviations}

ABC: ATP-binding cassette; Adda: (2S,3S,8S,9S)-3-amino-9-methoxy-2,6,8trimethyl-10-phenyldeca-4,6-dienoic acid; CA: Carbonic anhydrase; CHAPS: [(3-Cholamidopropyl)dimethylammonio]-1-Propanesulfonic Acid; OD: Optic density; DTT: Dithiotreitol; FBA: Fructose-1,6-biphosphate aldolase; FBPase class II/SBPase: D-fructose-1,6-biphosphate classll/sedoheptulose 1,7biphosphate; FNR: Feredoxin-NADP ${ }^{+}$oxidoreductase;

GAPDH: Glyceraldehyde-3-phosphate dehydrogenase; $\mathrm{HCO}_{3}^{-}$: Carbonic acid; 
HPLC: High performance liquid chromatography; MALDI-TOF: Matrix assisted laser desorption ionization time of flight; NRPS: Non ribosomal peptide synthesase; PHA: Polyhydroxyalcanoate; pl: Isoelectric point; PKS: Polyketide synthase; PRK: Phosphoribulokinase; 2-DE: Bidimensional electrophoresis; DSD-PAGE: Sodium dodecil sulphate-poliacrylamide gel electrophoresis; SOD: Superoxide dismutase; Rubisco: Ribulose bisophosphate carboxylase: TCA: Trichloroacetic acid; Vh: Volt hours.

\section{Competing interests}

The authors declare that they have no competing interests and declare no conflict of interest.

\section{Authors' contributions}

AT: participated on study design and all experimental procedures as well as the manuscript draft. BPA: participated on experimental design, execution and manuscript draft. WCA: participated on experiment execution. AM: participated on protein identification. BSM: participated on protein identification. OLF: performed the study design and coordinated the manuscript draft. All authors read and approved the final manuscript.

\section{Acknowledgements}

The authors acknowledge grant support from CNPq, CAPES, FAP-DF, and Catholic University of Brasilia - Brazil.

\section{Author details}

'Centro de Análises Proteômicas e Bioquímicas, Universidade Católica de Brasília, Pós Graduação em Ciências Genômicas e Biotecnologia, SGAN 916

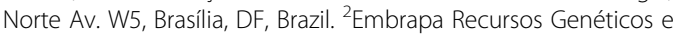
Biotecnologia, Brasília, DF, Brazil. ${ }^{3}$ Departamento de Biologia, Universidade Federal de Juiz de Fora, Juiz de Fora, MG, Brazil.

Received: 10 January 2012 Accepted: 9 May 2012

Published: 7 June 2012

\section{References}

1. Baldia SF, Conaco MCG, Nishijima T, Imanishi S, Harada K-I: Microcystin production during algal bloom occurrence in Laguna de Bay, the Philippines. Fish Sci 2003, 69:110-116.

2. Bormans M, Ford PW, Fabbro L, Hancock G: Onset and persistence of cyanobacterial blooms in a large impounded tropical river, Australia. Mar Freshw Res 2004, 55:1-15.

3. Lehman PW, Boyer G, Hall C, Waller S, Gehrts K: Distribution and toxicity of a new colonial Microcystis aeruginosa bloom in the San Francisco Bay Estuary, California. Hydrobiologia 2005, 541:87-99.

4. Rolland A, Bird DF, Giani A: Seasonal changes in composition of the cyanobacterial community and the occurrence of hepatotoxic blooms in the eastern townships, Québec, Canada. J Plankton Res 2005, 27:683-694.

5. Costa IAS, Azevedo SMFO, Senna PAC, Bernardo RR, Costa SM, Chellappaellappa NT: Occurrence of toxin-producing cyanobacteria blooms in a brazilian semiarid reservoir. Braz J Biol 2006, 66:211-219.

6. Francis G: Poisonous Australian lake Nature; 1878:18.

7. Andersen RJ, Luu HA, Chen DZX, Holmes CFB: Chemical and biological evidence links microcystins to salmon 'netpen liver disease'. Toxicon 1993, 31:1315-1323.

8. Mez K, Hanselmann K, Naegeli H, Preisig H: Protein phosphatase-inhibiting activity in cyanobacteria from alpine lakes in Switzerland. Phycologia 1996, 36:133-139.

9. Carmichael WW: Health effects of toxin-producing cyanobacteria: "The CyanoHABs". Hum Ecol Risk Assess 2001, 7:1393-1407.

10. Azevedo SM, Carmichael WW, Jochimsen EM, Rinehart KL, Lau S, Shaw GR, Eaglesham GK: Human intoxication by microcystins during renal dialysis treatment in Caruaru-Brazil. Toxicology 2002, 181-182:441-446.

11. Carmichael WW: The toxins of cyanobacteria. Sci Am 1994, 270:78-86.

12. Welker $\mathrm{M}$, von Dohren $\mathrm{H}$ : Cyanobacterial peptides - nature's own combinatorial biosynthesis. FEMS Microbiol Rev 2006, 30:530-563.

13. Song L, Sano T, Li R, Watanabe MM, Liu Y, Kaya K: Microcystin production of Microcystis viridis (cyabobacteria) under different culture conditions. Phycol Res 1998, 46:19-23.

14. Sivonen K, Jones G: Cyanobacterial Toxins. In Toxic Cyanobacteria in Water: A guide to their public health consequences, monitoring and management. Edited by Chorus IB.: J WHO; 1999:400.
15. Lee SJ, Jang MH, Kim HS, Yoon BD, Oh HM: Variation of microcystin content of microcystis aeruginosa relative to medium N:P ratio and growth stage. J App/ Microbiol 2000, 89:323-329.

16. Kaneko T, Nakajima N, Okamoto S, Suzuki I, Tanabe Y, Tamaoki M, Nakamura Y, Kasai F, Watanabe A, Kawashima K, et al: Complete genomic structure of the bloom-forming toxic cyanobacterium Microcystis aeruginosa NIES843. DNA Res 2007, 14:247-256.

17. Tillett D, Dittmann E, Erhard M, von Dohren H, Borner T, Neilan BA: Structural organization of microcystin biosynthesis in Microcystis aeruginosa PCC7806: an integrated peptide-polyketide synthetase system. Chem Biol 2000, 7:753-764.

18. Christiansen G, Fastner J, Erhard M, Borner T, Dittmann E: Microcystin biosynthesis in planktothrix: genes, evolution, and manipulation. J Bacteriol 2003, 185:564-572.

19. Rouhiainen L, Vakkilainen T, Siemer BL, Buikema W, Haselkorn R, Sivonen K Genes coding for hepatotoxic heptapeptides (microcystins) in the cyanobacterium Anabaena strain 90. Appl Environ Microbiol 2004, 70:686-692

20. Fulda S, Huang F, Nilsson F, Hagemann M, Norling B: Proteomics of Synechocystis sp. strain PCC 6803. Identification of periplasmic proteins in cells grown at low and high salt concentrations. Eur J Biochem 2000, 267:5900-5907.

21. Huang F, Hedman E, Funk C, Kieselbach T, Schroder WP, Norling B: Isolation of outer membrane of Synechocystis sp. PCC 6803 and its proteomic characterization. Mol Cell Proteomics 2004, 3:586-595.

22. Huang F, Parmryd I, Nilsson F, Persson AL, Pakrasi HB, Andersson B, Norling B: Proteomics of Synechocystis sp. strain PCC 6803: identification of plasma membrane proteins. Mol Cell Proteomics 2002, 1:956-966.

23. Srivastava R, Pisareva T, Norling B: Proteomic studies of the thylakoid membrane of Synechocystis sp. PCC 6803. Proteomics 2005, 5:4905-4916.

24. Pisareva T, Kwon J, Oh J, Kim S, Ge C, Wieslander A, Choi JS, Norling B: Model for membrane organization and protein sorting in the cyanobacterium Synechocystis sp. PCC 6803 inferred from proteomics and multivariate sequence analyses. J Proteome Res 2011, 10:3617-3631.

25. Simon WJ, Hall JJ, Suzuki I, Murata N, Slabas AR: Proteomic study of the soluble proteins from the unicellular cyanobacterium Synechocystis sp. PCC6803 using automated matrix-assisted laser desorption/ionizationtime of flight peptide mass fingerprinting. Proteomics 2002, 2:1735-1742.

26. Kurian D, Phadwal K, Maenpaa P: Proteomic characterization of acid stress response in Synechocystis sp. PCC 6803. Proteomics 2006, 6:3614-3624.

27. Barrios-Llerena ME, Reardon KF, Wright PC: 2-DE proteomic analysis of the model cyanobacterium Anabaena variabilis. Electrophoresis 2007, 28:1624-1632.

28. Moslavac S, Bredemeier R, Mirus O, Granvogl B, Eichacker LA, Schleiff E: Proteomic analysis of the outer membrane of Anabaena sp. strain PCC 7120. J Proteome Res 2005, 4:1330-1338.

29. Gonzalez A, Bes MT, Peleato ML, Fillat MF: Unravelling the regulatory function of FurA in Anabaena sp. PCC 7120 through 2-D DIGE proteomic analysis. J Proteomics 2011, 74:660-671.

30. Cardona T, Battchikova N, Agervald A, Zhang P, Nagel E, Aro EM, Styring S, Lindblad P, Magnuson A: Isolation and characterization of thylakoid membranes from the filamentous cyanobacterium Nostoc punctiforme. Physiol Plant 2007, 131:622-634.

31. Hunsucker SW, Klage K, Slaughter SM, Potts M, Helm RF: A preliminary investigation of the Nostoc punctiforme proteome. Biochem Biophys Res Commun 2004, 317:1121-1127.

32. Srivastava AK, Bhargava P, Thapar R, Rai LC: Salinity-induced physiological and proteomic changes in Anabaena doliolum. Environ Exp Bot 2008, 64:49-57.

33. Pandhal J, OW SW, Wright PC, Biggs CA: Comparative proteomics study of salt tolerance between a nonsequenced extremely halotolerant cyanobacterium and its mildly halotolerant relative using in vivo metabolic labeling and in vitro isobaric labeling. J Proteome Res 2009, 8:818-828.

34. Choi J-S, Kim D-S, Lee J, Kim S-J, Eady RA: Proteomic analisys of ligthinduced proteins in Synechocystis sp. PCC 6803: Identification of proteins separated by 2D- PAGE using $\mathrm{N}$-terminal sequencing and MALDI-TOF MS. Mol Cells 2000, 10:705-711.

35. Gao Y, Xiong W, Li XB, Gao CF, Zhang YL, Li H, Wu QY: Identification of the proteomic changes in Synechocystis sp. PCC 6803 following prolonged UV-B irradiation. J Exp Bot 2009, 60:1141-1154.

36. Hongsthong A, Sirijuntarut M, Prommeenate P, Lertladaluck K, Porkaew K, Cheevadhanarak S, Tanticharoen M: Proteome analysis at the subcellular 
level of the cyanobacterium Spirulina platensis in response to lowtemperature stress conditions. FEMS Microbiol Lett 2008, 288:92-101.

37. Zhang LF, Yang HM, Cui SX, Hu J, Wang J, Kuang TY, Norling B, Huang F: Proteomic analysis of plasma membranes of cyanobacterium Synechocystis sp. Strain PCC 6803 in response to high pH stress. J Proteome Res 2009, 8:2892-2902.

38. Ekman M, Tollback P, Bergman B: Proteomic analysis of the cyanobacterium of the Azolla symbiosis: identity, adaptation, and $\mathrm{NifH}$ modification. J Exp Bot 2008, 59:1023-1034.

39. Ekman M, Tollback P, Klint J, Bergman B: Protein expression profiles in an endosymbiotic cyanobacterium revealed by a proteomic approach. Mol Plant Microbe Interact 2006, 19:1251-1261.

40. Dittmann E, Erhard M, Kaebernick M, Scheler C, Neilan BA, von Dohren $H_{\text {, }}$ Borner T: Altered expression of two light-dependent genes in a microcystin-lacking mutant of Microcystis aeruginosa PCC 7806. Microbiology 2001, 147:3113-3119.

41. Alexova R, Haynes PA, Ferrari BC, Neilan BA: Comparative protein expression in different strains of the bloom-forming cyanobacterium Microcystis aeruginosa. Mol Cell Proteomics 2011, 10:M110. 003749.

42. Arment AR, Carmichael WW: Evidence that microcystin is a thio-template product. J Phycol 1996, 32:591-597.

43. Bateman KP, Thibault P, Douglas DJ, White RL: Mass spectral analyses of microcystins from toxic cyanobacteria using on-line chromatographic and electrophoretic separations. J Chromatogr A 1995, 712:253-268.

44. Yuan M, Namikoshi M, Otsuki A, Rinehart KL, Sivonen K, Watanabe MF: Lowenergy collisionally activated decomposition and structural characterization of cyclic heptapeptide microcystins by electrospray ionization mass spectrometry. J Mass Spectrom 1999, 34:33-43.

45. Oksanen I, Jokela J, Fewer DP, Wahlsten M, Rikkinen J, Sivonen K: Discovery of rare and highly toxic microcystins from lichen-associated cyanobacterium Nostoc sp. strain IO-102-I. Appl Environ Microbiol 2004, 70:5756-5763.

46. Funari $E$, Testai $E$ : Human health risk assessment related to cyanotoxins exposure. Crit Rev Toxicol 2008, 38:97-125.

47. Koksharova OA, Klint I, Rasmussen U: The first protein map of Synechococcus sp. strain PCC 7942. Mikrobiologiia 2006, 75:765-774.

48. Klint J, Ran L, Rasmussen U, Bergman B: Identification of developmentally regulated proteins in cyanobacterial hormogonia using a proteomic approach. Symbiosis 2006, 41:87-95.

49. Degrelle SA, Le Blomberg A, Garrett WM, Li RW, Talbot NC: Comparative proteomic and regulatory network analyses of the elongating pig conceptus. Proteomics 2009, 9:2678-2694.

50. Richardson MR, Lai X, Dixon JL, Sturek M, Witzmann FA: Diabetic dyslipidemia and exercise alter the plasma low-density lipoproteome in Yucatan pigs. Proteomics 2009, 9:2468-2483.

51. Wu Z, Zhang W, Lu C: Comparative proteome analysis of secreted proteins of Streptococcus suis serotype 9 isolates from diseased and healthy pigs. Microb Pathog 2008, 45:159-166.

52. Stead D, Findon H, Yin Z, Walker J, Selway L, Cash P, Dujon BA, Hennequin C, Brown AJ, Haynes K: Proteomic changes associated with inactivation of the Candida glabrata ACE2 virulence-moderating gene. Proteomics 2005, 5:1838-1848.

53. Chromy BA, Choi MW, Murphy GA, Gonzales AD, Corzett CH, Chang BC, Fitch JP, McCutchen-Maloney SL: Proteomic characterization of Yersinia pestis virulence. J Bacterio/ 2005, 187:8172-8180.

54. Lan CY, Newport G, Murillo LA, Jones T, Scherer S, Davis RW, Agabian N: Metabolic specialization associated with phenotypic switching in Candidaalbicans. Proc Natl Acad Sci U S A 2002, 99:14907-14912.

55. Cavet JS, Borrelly GP, Robinson NJ: Zn, Cu and Co in cyanobacteria: selective control of metal availability. FEMS Microbiol Rev 2003, 27:165-181.

56. Coleman JRI: Carbonic anhydrase and its role in photosynthesis In Photosynthesis: Physiology and Metabolism. Edited by Leegood RCS, Von Caemmerer TD, Kluwer S.; 2004:625.

57. Welsh EA, Liberton M, Stockel J, Loh T, Elvitigala T, Wang C, Wollam A, Fulton RS, Clifton SW, Jacobs JM, et al: The genome of Cyanothece 51142, a unicellular diazotrophic cyanobacterium important in the marine nitrogen cycle. Proc Natl Acad Sci U S A 2008, 105:15094-15099.

58. Morand LZ, Cheng RH, Krogmann DW, Ki Ho K: Soluble electron transfer catalysts of cyanobacteria: 2004
59. Hosoya-Matsuda N, Motohashi K, Yoshimura H, Nozaki A, Inoue K, Ohmori $M$, Hisabori T: Anti-oxidative stress system in cyanobacteria. Significance of type II peroxiredoxin and the role of 1-Cys peroxiredoxin in Synechocystis sp. strain PCC 6803. J Biol Chem 2005, 280:840-846.

60. Dietz KJ, Stork T, Finkemeier I, Lamkemeyer P, Li W-X, El-Tayeb MA, Michel K-P, Pistorius E, Baier M: The Role of Peroxiredoxins in Oxygenic Photosynthesis of Cyanobacteria and Higher Plants: Peroxide Detoxification or Redox Sensing? In Edited by Demmig-Adams B, Adams WW III, Matoo AK.: Springer; 2008.

61. Regelsberger G, Laaha U, Dietmann D, Ruker F, Canini A, Grilli-Caiola M, Furtmuller PG, Jakopitsch C, Peschek GA, Obinger C: The iron superoxide dismutase from the filamentous cyanobacterium Nostoc PCC 7120. Localization, overexpression, and biochemical characterization. J Biol Chem 2004, 279:44384-44393.

62. Taroncher-Oldenburg G, Nishina K, Stephanopoulos G: Identification and analysis of the polyhydroxyalkanoate-specific beta-ketothiolase and acetoacetyl coenzyme $A$ reductase genes in the cyanobacterium Synechocystis sp. strain PCC6803. Appl Environ Microbiol 2000, 66:4440-4448.

63. Hanikenne M, Kramer U, Demoulin V, Baurain D: A comparative inventory of metal transporters in the green alga Chlamydomonas reinhardtii and the red alga Cyanidioschizon merolae. Plant Physiol 2005, 137:428-446.

64. Hongsthong A, Sirijuntarut M, Yutthanasirikul R, Senachak J, Kurdrid P Cheevadhanarak S, Tanticharoen M: Subcellular proteomic characterization of the high-temperature stress response of the cyanobacterium Spirulina platensis. Proteome Sci 2009, 7:33

65. Amnuaykanjanasin A, Daub ME: The ABC transporter ATR1 is necessary for efflux of the toxin cercosporin in the fungus Cercospora nicotianae. Fungal Genet Biol 2009, 46:146-158.

66. Gerbersdorf SU: An advanced technique for immuno-labelling of microcystins in cryosectioned cells of Microcystis aeruginosa PCC 7806 (cyanobacteria): implementations of an experiment with varying light scenarios and culture densities. Toxicon 2006, 47:218-228.

67. Young FM, Thomson C, Metcalf JS, Lucocq JM, Codd GA: Immunogold localisation of microcystins in cryosectioned cells of Microcystis. J Struct Biol 2005, 151:208-214.

68. Jungmann D, Benndorf J: Toxicity to Daphnia of a compound extracted from laboratory and natural Microcystis spp., and the role of microcystins. Freshw Biol 1994, 32:13-20.

69. Lampert W: Further studies on the inhibitory effect of toxic blue-green Microcystis aeruginosa on the filtering rate of zooplankton. Arch Hydrobiol 1982, 95:207-220.

70. Meibner K, Dittmann E, Biirner T: Toxic and non-toxic strains of the cyanobacterium Microcystis aeruginosa contain sequences homologous to peptide synthetase genes. FEMS Microbiol Lett 1996, 135:295-303.

71. Kardinaal WEA, Tonk L, Janse I, Hol S, Slot P, Huisman J, Visser PM: Competition for light between toxic and nontoxic strains of the harmful cyanobacterium microcystis. App/ Environ Microbio/ 2007, 73:2939-2946.

72. Christiansen G, Molitor C, Philmus B, Kurmayer B: Nontoxic strains of cyanobacteria are the result of major gene deletion events induced by a transposable element. Mol Biol Evol 2008, 25(8):1695-1704.

73. Harada K-i, Kondo F, Lawton L: Laboratory analysis of cyanotoxins. In Toxic Cyanobacteria in Water: A guide to their public health consequences, monitoring and management. Edited by Chorus IB.: J. WHO; 1999:400.

74. Shevchenko A, Wilm M, Vorm O, Mann M: Mass spectrometric sequencing of proteins silver-stained polyacrylamide gels. Anal Chem 1996, 68:850-858.

doi:10.1186/1477-5956-10-38

Cite this article as: Tonietto et al.: Comparative proteomics between natural Microcystis isolates with a focus on microcystin synthesis. Proteome Science 2012 10:38. 